\title{
Canine pyometra: interferences of age and type in blood count and serum biochemistry*
}

\section{Piometra canina: interferências da idade e tipo sobre o hemograma e a bioquímica sérica}

\author{
Mariana Santos dos Anjos, ${ }^{* *}$ Rodrigo Freitas Bittencourt, ${ }^{* *}$ Carmo Emanuel Almeida Biscarde, ${ }^{* *}$ \\ Mariana Alves de Andrade Silva, ${ }^{* *}$ Elisiane Sateles dos Santos, ${ }^{* *}$ Luiz Di Paolo Maggitti Junior, ${ }^{* *}$ \\ Larissa Rodrigues Santana, ${ }^{* *}$ Morgana Duarte Felix, ${ }^{* *}$ Marta Vasconcelos Bittencourt, ${ }^{* *}$ \\ Ana Karina da Silva Cavalcante***
}

\begin{abstract}
Hematological and serum biochemical characteristics and prevalence of microorganisms in the uterine content of bitches with pyometra were described, according to type and age. This study was carried out at the Veterinary Medicine Hospital Renato Rodenburg de Medeiros Netto of the UFBA with 132 patients diagnosed with pyometra through imaging and laboratory tests, divided into two groups: Group 1 - less than eight years $(n=72)$ and Group 2 - more than eight years $(n=60)$. Both groups were submitted to Ovariohysterectomy $(\mathrm{OH})$, in which blood and uterine lumen secretion samples were collected. The highest incidence of pyometra was found in bitches under 8 years (54.5\%), Poodle breed (31.8\%) and mixed-breed (27.3\%). Open pyometra represented $80.3 \%$ of all cases. The death rate $(6.0 \%)$ did not show significant difference between the types. Anemia (73.0\%), thrombocytopenia $(41.2 \%)$ and leukocytosis (77.0\%) were observed. Urea and ALP were above the reference values in $41.8 \%$ and $52.2 \%$ of each group, respectively, while ALT (94.0\%) and creatine (82\%) remained normal in most animals. Serum biochemistry did not show significant differences $(\mathrm{P}<0.05)$. Escherichia coli and Klebsiella sp. grew in $33.3 \%$ and $16.7 \%$ of the samples, respectively. Therefore, no significant hematological and serum biochemical differences were observed in bitches with pyometra in both age categories.
\end{abstract}

Keywords: Cystic endometrial hyperplasia complex, Dog, Infection, Uterus.

\section{Resumo}

Descreveu-se características hematológicas, bioquímicas séricas e prevalência de microrganismos no conteúdo uterino de cadelas com piometra, de acordo com o tipo e idade. Realizou-se este estudo no Hospital de Medicina Veterinária Renato Rodenburg de Medeiros Netto da UFBA com 132 pacientes diagnosticadas com piometra, por exames de imagem e laboratoriais, divididas em dois grupos: Grupo 1 - menos de oito anos $(n=72)$ e Grupo 2 - mais de oito anos $(n=60)$, submetidas a Ovariectomia $(O H)$, quando se coletou amostras de sangue e secreção do lúmen uterino. A incidência maior deu-se em cadelas abaixo de 8 anos (54,5\%), da raça Poodle (31,8\%) e sem raça definida (SRD) $(27,3 \%)$, sendo $80,3 \%$ de piometra aberta. A taxa de óbito $(6,0 \%)$ não apresentou diferença significativa entre os tipos. Observou-se a ocorrência de anemia (73,0\%), trombocitopenia (41,2\%) e leucocitose ( $77,0 \%)$. Os valores de ureia e FA estiveram acima dos valores de referência em 41,8\% e 52,2\% das cadelas respectivamente, enquanto a $\operatorname{ALT}(94,0 \%)$ e a creatina ( $82 \%)$ mantiveram-se dentro dos valores de referência na maioria dos animais. A bioquímica sérica não apresentou diferenças significativas $(\mathrm{P}<0,05)$. Observou-se crescimento de Escherichia coli e Klebsiella sp. em $33,3 \%$ e $16,7 \%$ das amostras, respectivamente. Sendo assim, não se observou diferenças significativas hematológicas e na bioquímica sérica de cadelas com piometra nas categorias de idade.

Palavras-chave: cão, hiperplasia endometrial cística, infecção, útero.

\section{Introduction}

Pyometra is caused by a hormonal imbalance and consequent cystic endometrial hyperplasia (KUMAR and SAXENA, 2018), bacterial virulence and the capacity of each individual to exhibit a response to the infectious process (HAGMAN, 2014); in the diestrus phase of the estral cycle and presents a high incidence, reaching mainly middle-aged animals (SMITH, 2006).
Estrogen works by relaxing the cervix, allowing microorganisms of the vaginal microbiota to enter the uterus during proestrus and estrus, and increasing the number of progesterone receptors in the endometrium, which leads to the proliferation of endometrial glands and enhancement of their function, resulting in intensification of fluid secretion, besides causing the closure of the cervix. Secretion provides an environment favorable to bacterial growth and associated with reduced

*Recebido em 10 de março de 2021 e aceito em 16 de agosto de 2021.

**Escola de Medicina Veterinária e Zootecnia - EMEVZ, Universidade Federal da Bahia (UFBA), Salvador, Bahia, Brasil.

${ }^{* * *}$ Centro de Ciências Agrárias, Ambientais e Biológicas - CCAAB, Universidade Federal do Recôncavo da Bahia (UFRB), Cruz das Almas, Bahia, Brasil. karina@ufrb.edu.br. 
inflammatory response, favors the establishment of the disease (SHAH et al., 2017).

The most frequently microorganisms from the uterus of bitches with pyometra is Escherichia coli, Streptococcus sp., Klebsiella sp., Staphylococcus sp. and Pseudomonas sp. (FELDMAN and NELSON, 2004; SUGIURA et al., 2004; SMITH, 2006; KALENSKI et al., 2012; FIAMENGO et al., 2020).

Pyometra's infectious process can induce leukocytosis, anemia, increased urea and creatinine (indicators of kidney injury), changes in liver enzymes such as Alanine Aminotransferase and Alkaline Phosphatase and increased Total Plasma Proteins (SHAH et al., 2017; SRINIVAS et al., 2018). In addition, serious complications such as endotoxemia and septicemia can occur, leading to it being treated as an emergency (HAGMAN, 2012).

To evaluate all these elements is of utmost importance, as they indicate the seriousness of the condition and the prognosis of the disease, which is closely linked to awareness of these changes and early diagnosis. Thus, this work aimed to study the hematological and serum biochemical characteristics of bitches with pyometra, in different age groups and types, as well as to indicate the etiological agents involved in the process.

\section{Material and Methods}

For this work 132 bitches of 21 different breeds, diagnosed with pyometra, with ages ranging from 9 months to 17 years, were studied at a University Hospital of Veterinary Medicine.

All data were captured in individual data capture forms. Information such as: breed, age, weight, medication use, previous diseases, and chief complaint, heart and respiratory rates, temperature, color of the mucosa, capillary refill time, hydration, pulse, body condition and facies. In addition, the ocular, auditory, digestive, respiratory, cardiovascular, nervous, locomotor, urinary and tegumentary systems were also examined, and the specific examination of the reproductive system was also carried out.

All bitches were submitted to ultrasonography, serum biochemistry (alanine aminotransferase - ALT, Alkaline Phosphatase ALP, creatinine and urea) and complete blood count - CBC (Hemoglobin, Hematocrit, Mean Corpuscular Volume - MCV, Mean Corpuscular Hemoglobin Concentration - MCHC, Platelets, Metarubricyte, Total Plasma Proteins - TPP, Leukocytes, Myelocytes, Metamyelocytes, Band neutrophils, Lymphocytes, Monocytes and Eosinophils). Images of the uterus and uterine horns were obtained, and the diagnosis of pyometra was confirmed by increased dimensions, hypoechoic content in the uterine lumen and endometrium thickening in the ultrasound examination (Z5 Mindray ${ }^{\circledR}$ 5-8 MHz micro-convex transducer). Shortly after the ultrasound diagnosis, the blood samples were sterilely collected from the cephalic, jugular or femoral veins for CBC $(\mathrm{pocH}-100 \mathrm{iV} \circledast$, Sysmex, USA) and serum biochemistry laboratory tests (Labtest $\AA$, Diagnóstica AS, BRA) (BIOPLUS 200®, BRA), and immediately transferred $(2 \mathrm{~mL})$ to tubes containing ethylenediaminetetraacetic acid (for $\mathrm{CBC}$ ) or to a tube without anticoagulant (for serum biochemistry). The samples were analyzed in the Clinical Analysis Laboratory, at the hospital, within two hours.

Positive cases with vulvar discharge of uterine content were classified as open pyometra and those without vulvar discharge as closed pyometra (SMITH, 2006).
The bitches were submitted to therapeutic ovariohysterectomy $(\mathrm{OH})$ using the traditional technique (FOSSUM, 2013). Immediately after surgery, samples of uterine contents of both uterine horns were collected by puncture using a disposable syringe and sterile needle. The material was sent for bacterial culture, isolation and antibiogram. The collected material was transferred to sterile glass tubes containing a maintenance medium (Lauryl Tryptose Broth) and sent to the Bacteriology Laboratory.

Some of the studied parameters could not be observed in the 132 animals and for several reasons they were considered lost plots, such as not performing tests at the hospital by choice of the owner or even by death of the patient.

The statistical design employed was entirely randomized, in which the animals of the study were considered the repetitions and in the experimental groups the animals less than eight years old (Group 1, $n=72$ ) or more than eight years old (Group 2, $\mathrm{n}=60$ ) were considered and in a second study, the experimental treatments were the animals with open pyometra $(n=94)$ or closed $(n=23)$.

The Statistical Analysis System (SAS) - version 9.2 was used for the statistical analysis of the evaluated characteristics. Thus, the following sequence of analyses was performed.

The consistency of the data and the descriptive analysis (average and standard deviation) of the characteristics of interest: ALT, ALP, Creatinine, Urea, Hemoglobin, Hematocrit, MCV, MCHC, Platelets, Metarubricyte, TPP, Leukocytes, Myelocytes, Metamyelocytes, Band neutrophils, Lymphocytes, Monocytes and Eosinophils were performed using the MEANS Procedure (PROC MEANS). The parameters were analyzed for normality of the distribution using the Shapiro-Wilk test. The variables with non-normal distribution were submitted to the Kruskal-Wallis test to observe possible differences between the experimental groups. For the variables with normal distribution the analysis of variance (ANOVA) was performed using the General Linear Model Procedure (PROC GLM). And to compare the averages the Tukey-Kramer test was used. For all analyses the five percent probability level was established.

This study met the requirements imposed by the Ethics Committee on Animal Experimentation (ECAE) in accordance with the norms edited by the National Council for Animal Experimentation Control (NCAEC) and was approved by the ECAE of the College of Veterinary Medicine and Animal Science of the Federal University of Bahia, registered under No. 10/2017.

\section{Results}

The bitches with pyometra, in the Veterinary Hospital, were from 21 different breeds, being 42 Poodle (32.6\%), 36 mixed-breed (27.3\%), 8 Yorkshire (6.1\%), 15 Pinscher (11.4\%); 3 Chow Chow, 3 Pit Bull, 3 Rottweiller and 3 Shih Tzu (2.3\%, each), the most frequent breeds and the remaining 19 bitches (14.4\%) were classified as other breeds.

The average age of the affected patients was 8 years, 5 months and 25 days, being more frequent the occurrence of pyometra in animals with $8(32.8 \%)$ and $7(20.3 \%)$ years (Figure 1$)$. Of all the animals in the study, $54.5 \%$ were under 8 years old $(n=72)$ and $45.5 \%(n=60)$ were over 8 years old. 
Figure 1: Graphic representation of the percentage of pyometra cases in relation to the age of bitches presented at the University Hospital of Veterinary Medicine

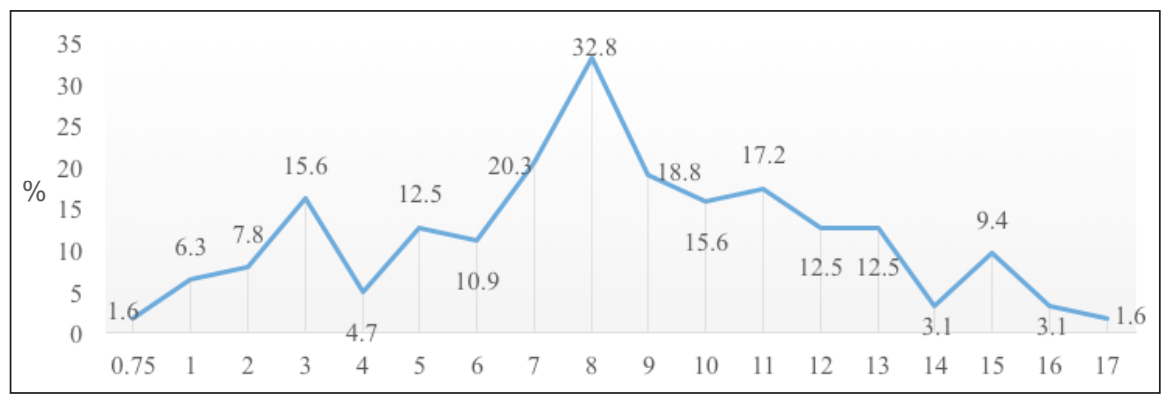

Between the types of pyometra ( $n=117), 80.3 \%$ of the animals had open cervix pyometra $(n=94)$, of these, $57.4 \%$ were less than 8 years old. The other 23 animals had closed cervix, $52.2 \%$ of which were less than 8 years old (Figure 2). The overall death rate was $6 \%$ and no significant differences were found in the incidence of pyometra types between age groups $(P>0.05)$.

On Table 1, it can be observed the general averages of the hematological parameters of bitches diagnosed with pyometra.

Figure 2: Graphic representation of the percentage of cases of pyometra in females attended at the UFBA Veterinary Medicine Hospital: A: Regarding the type (open or closed). B: According to age

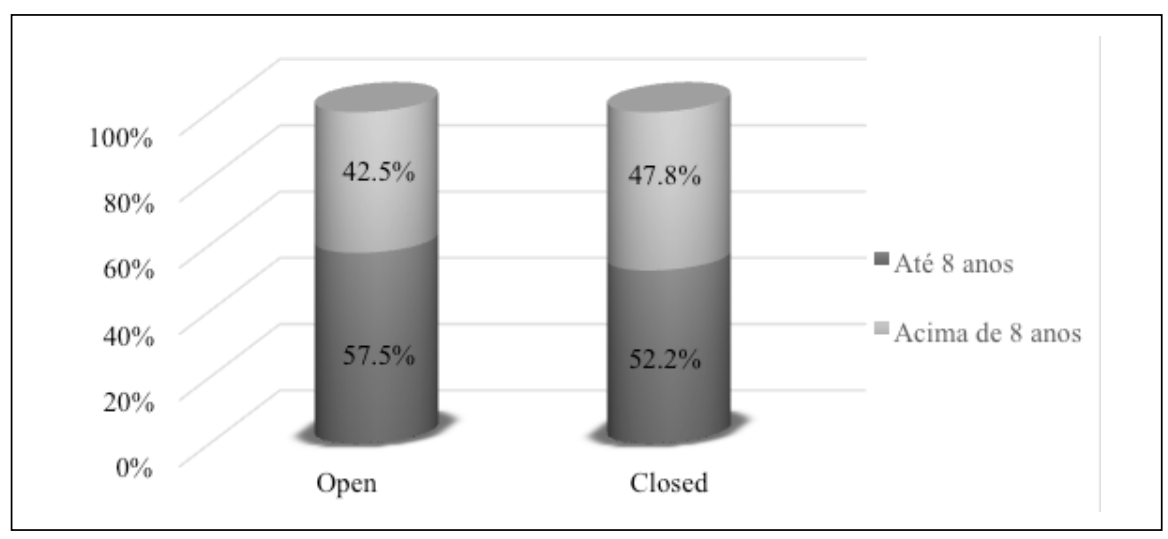

Table 1: General average and standard deviations of the hematological parameters of the bitches of the study with pyometra

\begin{tabular}{|c|c|}
\hline Variable & Average \pm SD \\
\hline $\operatorname{RBC}\left(x 10^{6} / \mu \mathrm{L}\right)$ & $5.10 \pm 1.45$ \\
\hline Hemoglobins (g/dL) & $11.42 \pm 3.31$ \\
\hline Hematocrit (\%) & $33.93 \pm 9.24$ \\
\hline $\operatorname{MCV}(f L)$ & $65.77 \pm 7.79$ \\
\hline MCHC (\%) & $32.96 \pm 3.70$ \\
\hline Platelets $(/ \mu \mathrm{L})$ & $269,544.90 \pm 15,6496.70$ \\
\hline Metarubricytes (/100Le) & $1.30 \pm 5.80$ \\
\hline TPP (g/dL) & $7.98 \pm 1.76$ \\
\hline 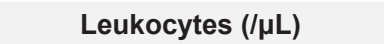 & $35,551.06 \pm 2,7968.55$ \\
\hline Myelocytes $(/ \mu \mathrm{L})$ & $115.93 \pm 366.50$ \\
\hline Metamyelocytes $(/ \mu \mathrm{L})$ & $781.01 \pm 2,443.15$ \\
\hline Band neutrophils $(/ \mu L)$ & $5,733.37 \pm 9,371.17$ \\
\hline Segmented neutrophils $(/ \mu L)$ & $2,2475.94 \pm 16,599.27$ \\
\hline 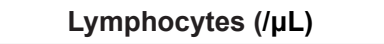 & $3,494.29 \pm 2,661.43$ \\
\hline 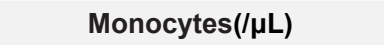 & $2,461.34 \pm 2,929.78$ \\
\hline Eosinophils $(/ \mu \mathrm{L})$ & $853.19 \pm 1,118.41$ \\
\hline
\end{tabular}


Anemia was observed in $72 \%$ of the animals, and $65 \%$ of these presented normocytic normochromic anemia classified. Similarly, leukocytosis also appeared with a frequency higher than $70 \%$. Left shift was found in $60.58 \%$ of all cases, of which $93.65 \%$ had regenerative left shifts. The averages of leukocytes in the different age groups and types of pyometra were well above the reference values for the species, with counts above 30,000 leukocytes $/ \mu \mathrm{L}$. Thrombocytopenia was found in $41.2 \%$ of the studied bitches and hyperproteinemia in $49.0 \%$ of them.
Regarding the frequencies of the biochemical alterations studied renal function indicators showed an increase of $41.8 \%$ in the serum urea levels and $18.0 \%$ of them presented increased creatinine. Concerning the hepatic enzymes, ALP was above the reference values for the species in $52.2 \%$ of females studied, and ALT in only $3.3 \%$ of them.

When comparing $\mathrm{CBC}$ values between the age groups, no significant differences $(P<0.05)$ were observed, as well as between types of pyometra, Table 2 .

Table 2: Comparison of the CBC of bitches with pyometra in age groups (up to 8 years and over 8 years) and in type groups (open and closed pyometra)

\begin{tabular}{|c|c|c|c|c|}
\hline Variable & Up to 8 years & Over 8 years & Open pyometra & Closed pyometra \\
\hline $\operatorname{RBC}\left(\times 10^{6} / \mu \mathrm{L}\right)$ & $5.36 \pm 1.49$ & $5.11 \pm 1.39$ & $5.12 \pm 1.44$ & $5.76 \pm 1.22$ \\
\hline Hemoglobin (g/dL) & $11.56 \pm 3.57$ & $11.27 \pm 2.97$ & $11.24 \pm 3.18$ & $12.61 \pm 3.38$ \\
\hline Hematocrit (\%) & $34.60 \pm 9.23$ & $33.28 \pm 9.33$ & $33.12 \pm 8.90$ & $37.57 \pm 9.06$ \\
\hline $\operatorname{MCV}(f L)$ & $64.90 \pm 9.12$ & $66.98 \pm 5.79$ & $65.64 \pm 8.87$ & $65.84 \pm 3.89$ \\
\hline $\mathrm{MCHC}(\%)$ & $33.73 \pm 2.41$ & $32.15 \pm 4.86$ & $33.412 \pm 2.26$ & $33.50 \pm 2.32$ \\
\hline Platelets $(/ \mu L)$ & $\begin{array}{c}244,009.62 \pm \\
146,349.50\end{array}$ & $\begin{array}{c}297,369.77 \pm \\
148,305.34\end{array}$ & $\begin{array}{c}263,220.00 \pm \\
157,546.80\end{array}$ & $\begin{array}{c}324,833.33 \pm \\
169,476.10\end{array}$ \\
\hline Metarubricytes (/100Le) & $0.78 \pm 1.40$ & $2.14 \pm 9.04$ & $1.68 \pm 7.03$ & $0.33 \pm 0.82$ \\
\hline TPP (g/dL) & $8.07 \pm 1.68$ & $7.90 \pm 1.80$ & $8.11 \pm 1.6$ & $7.90 \pm 1.62$ \\
\hline Leukocytes $(/ \mu L)$ & $36,485.39 \pm 30,179.96$ & $34,854.00 \pm 26,348.96$ & $34,688.65 \pm 22,725.51$ & $35,560.52 \pm 33,761.10$ \\
\hline Myelocytes $(/ \mu L)$ & $125.12 \pm 408.31$ & $110.68 \pm 318.36$ & $106.31 \pm 329.99$ & $107.64 \pm 402.76$ \\
\hline Metamyelocytes $(/ \mu L)$ & $955.08 \pm 3.086 .59$ & $606.83 \pm 1,395.89$ & $841.30 \pm 2.671 .59$ & $508.56 \pm 1.876 .92$ \\
\hline Band neutrophils $(/ \mu \mathrm{L})$ & $5,749.22 \pm 9.258 .51$ & $5,916.19 \pm 9,792.18$ & $5,368.28 \pm 8,292.92$ & $7,088.82 \pm 13,584.08$ \\
\hline Segmented neutrophils $(/ \mu L)$ & $21,962.10 \pm 18,560.77$ & $23,046.86 \pm 14,519.44$ & $21,005.35 \pm 12,487.17$ & $23,831.18 \pm 16,940.16$ \\
\hline Lymphocytes $(/ \mu \mathrm{L})$ & $3,791.49 \pm 2,676.41$ & $3,233.00 \pm 2,665.30$ & $3,706.33 \pm 2,756.88$ & $3,120.35 \pm 2,580.22$ \\
\hline Monocytes $(/ \mu \mathrm{L})$ & $2,576.86 \pm 3,037.60$ & $2,396.81 \pm 2,874.77$ & $2,237.46 \pm 2,301.42$ & $2,966.06 \pm 4,002.62$ \\
\hline 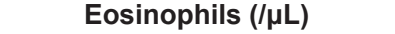 & $838.21 \pm 1,060.46$ & $857.67 \pm 1,205.85$ & $784.87 \pm 997.03$ & $1,208.65 \pm 1,645.62$ \\
\hline
\end{tabular}

RBC - Red Blood Count; GV - Globular Volume; MCV - Mean Corpuscular Volume; MCHC - Mean Corpuscular Hemoglobin Concentration; TPP - Total Plasma Proteins. The variables were submitted to the Kruskal-Wallis test (non-normal distribution) or Tukey-Kramer (normal distribution) to observe possible differences between the experimental groups with $\mathrm{P}<0.05$.

Similarly, when comparing the variables of serum biochemistry between age groups, no significant differences $(P<0.05)$ were found (Table3)

Table 3. Values for the serum biochemistry parameters of bitches with pyometra in age groups (up to 8 years and over 8 years) and type groups (open and closed pyometra)

\begin{tabular}{|c|c|c|c|c|c|}
\hline Variable & References value & Up to 8 years & Over 8 years & Open pyometra & Closed pyometra \\
\hline Urea (mg/dL) & $15-40 \mathrm{mg} / \mathrm{dL}$ & $56.35 \pm 66.45$ & $70.36 \pm 76.57$ & $68.54 \pm 81.02$ & $50.11 \pm 37.89$ \\
\hline Creatinine (mg/dL) & $0.5-1.5 \mathrm{mg} / \mathrm{dL}$ & $1.24 \pm 0.81$ & $1.62 \pm 2.02$ & $1.52 \pm 1.75$ & $1.19 \pm 0.61$ \\
\hline ALP (U/L) & 21-102U/L & $263.69 \pm 336.28$ & $247.25 \pm 286.75$ & $289.87 \pm 355.07$ & $509.31 \pm 1,296.05$ \\
\hline ALT (U/L) & $21-102 U / L$ & $36.18 \pm 16.20$ & $45.33 \pm 31.09$ & $38.39 \pm 26.19$ & $54.47 \pm 72.14$ \\
\hline
\end{tabular}

The variables were submitted to the Kruskal-Wallis test (non-normal distribution) or Tukey-Kramer (normal distribution) to observe possible differences between the experimental groups with $\mathrm{P}<0.05$.

The bacterial agent most frequently isolated in the cultures of uterine content from bitches of this study was Escherichia coli $(33.3 \%)$, then Klebsiella sp. (16.7\%), Enterobacter hafniae (5.0\%), Pseudomonas (5.0\%), Staphylococcus (5.0\%), Bacillus
(3.1\%), Streptococcus (3.1\%), Proteus mirabilis $(3.1 \%)$ and Micrococcus sp. (1,6\%). In $1.6 \%$ of the cultures there was contamination, showing yeast growth. In $20.0 \%$ of the cultures there was no bacterial growth. 


\section{Discussion}

The average age of the affected animals was consistent with other studies, which demonstrated that bitches over 8 years of age tend to be more affected by the disease than younger ones (FELDMAN and NELSON, 2004), as the responses caused by progesterone and estrogen in the uterus have a cumulative effect with each estral cycle (SMITH, 2006), however, exogenous estrogen administration can induce the disease in an ovariohysterectomy (STERMAN; MANKIN; BARTON, 2019) or puberty bitches. Unusually, a bitch of only 9 months of age of the Basset hound breed, with no history of use of exogenous hormones that showed values of RBC count and hematocrit were slightly above the reference values, which may indicate dehydration and the presence of leukopenia, or granulocytopenia (BARSANTI, 2012).

Several studies have suggested that the breed presents an important risk factor in the predisposition to the disease, as certain breeds are naturally more susceptible to developing pyometra than others, and this may happen due to the influence of genetic factors predisposing to the disease or due to the biological age characteristics of each breed, since animals of different breeds presenting the same chronological age can present different biological ages (EGENVALL et al., 2001). But there isn't a reasonable treatment for canine pyometra, one of the reasons for this may be due to doubts about the complex etiopathology of canine pyometra (Kumar and Saxena, 2018).

In a study based on data from a Swedish life insurance and veterinary care company and other studies cited by them, unlike our findings, the Poodle breed presented low risk for pyometra development, which may suggest a high influence of geographical location, as the popularity of certain breeds varies according to each region, resulting in different breed profiles in each country (EGENVALL et al., 2001). Other studies conducted in Brazil indicated a higher incidence of pyometra in mixedbreed animals, followed by the Poodle breed (COGGAN, 2005; MARTINS et al., 2015). In the present study, the Poodle breed presented a higher occurrence for the pathology, possibly due to the popularity of the breed in the study site, being superior to mixed-breed females.

Similarly, to other studies, it was found that open cervix pyometra had a higher incidence (MARTINS et al., 2015; JIPTEAN et al., 2017). The cause of this phenomenon is not known for sure, however, in a study by Weiss et al. (2004), it was observed that progesterone levels were higher in closed than in open pyometra, with a significant difference, but it was still not possible to establish a relationship between the type of pyometra and hormonal determinations of P4. In a study by Volpato (2011), in order to broaden the understanding of the mechanism of closing and opening of the cervix in this pathology, the hormonal concentrations of progesterone in types of pyometra were compared, but there were no significant differences as seen in the previous study. As in the studies by Prapaiwana et al. (2017), who evaluated the concentrations of receptors for estrogen, progesterone and oxytocin in the uterus and cervix of bitches with open and closed pyometra and found no differences between pyometra affected animals when compared to the concentrations of healthy animals.

The $6 \%$ lethality rate found in this study is within what is described in the literature. The prognosis of the disease after surgery is favorable and within one week, after successful surgical procedure and antimicrobial therapy, clinical signs are minimized, and the leukocyte count returns to normal reference limits. Death in the transoperative and immediate postoperative period occurs in about 5 to $8 \%$, but in cases of uterine rupture the lethality rate increases to $50 \%$ and bitches with severe azotemia also evolve to unfavorable prognosis (BARSANTI, 2012).

This finding probably indicates that there was delay in the search for veterinary assistance even after the observation of the clinical sign of vulvar discharge of the uterine content, since the outcome of the patient with open or closed pyometra depends primarily on the owner's speed in recognizing the clinical signs and taking the animal to the care of the qualified professional and not necessarily to the pyometra type (FELDMAN and NELSON, 2004). One study that reinforces this idea is by Sant'anna et al. (2014), which showed no significant difference in the prognosis of bitches with open or closed pyometra.

The anemia present in most cases, regardless of the type of pyometra and age group, may have occurred due to the migration of RBCs into the uterus by diapedesis in a chronic process or due to bone marrow suppression as a result of endotoxins from the systemic bacterial proliferation, which also causes leukocytosis (FELDMAN and NELSON, 2004). Animals with nonregenerative anemia in combination with azotemia, caused by renal dysfunction, probably produce less erythropoietin, further aggravating the anemic condition. It also occurs the reduction of serum iron levels, which is found high concentrations in the bone marrow, inside macrophages, as ferritin. This mechanism, in which there is a reduction in the bioavailability of iron, is a mechanism of the body to decrease bacterial growth, since this mineral is necessary for the development of microorganisms (THRALL et al., 2012).

The left shift leukocytosis observed is a reaction that reflects the infectious inflammatory process as well as the installed septicemia (SUGIURA et al., 2004). When the infection is severe and chronic, it can cause degenerative left shift (FELDMAN and NELSON, 2004).

In the present study, leukocytosis was present in both age groups and pyometra types and did not differ significantly $(P<0.05)$ between the open and closed types, which opposes the study of Jiptean et al. (2017), whose leukocyte count was significantly higher in animals with closed pyometra than in open but was similar to the results of Volpato (2011), which found no significant differences in leukocytosis in pyometra types.

The decrease in platelet count (thrombocytopenia) observed in some bitches with pyometra, probably occurs as a consequence of severe sepsis, which causes several disorders, resulting from decreased tissue perfusion or body dysfunction (NGUYEN et al., 2006; KALENSKI et al., 2012).

Although total plasma protein levels were close to reference values for the species in both the general average and the different types of pyometra and age groups, hyperproteinemia was frequent in this study. Total plasma proteins may be commonly found elevated in females with pyometra due to dehydration and/or chronic antigenic stimulation of the immune system as the production of immunoglobulins and complementary proteins may be increased in these cases (Feldman and Nelson, 2004; Srinivas et al., 2018). Total blood protein levels with no difference in animals with open and closed pyometra were also reported in the study by Gupta et al. (2013). 
However, it is known that urea may also be increased in other extra-renal changes, acute kidney injury is not an isolated event and it results in remote organ dysfunction to the lungs, heart, liver, intestines and brain through a pro-inflammatory mechanism that involves neutrophil cell migration, cytokine expression and increased oxidative stress (DE LOOR et al., 2013; MAKRIS; SPANOU, 2016). Increased kidney function indicators in serum (urea and creatinine) may occur as a result of immunocomplex deposition in the glomeruli, which in turn follows the endotoxemia caused by bacterial infection with Escherichia coli (FELDMAN and NELSON, 2004; MADDENS et al., 2010), Similar to what was observed in this experiment, urea and creatinine levels were elevated, possibly due to the presence of $\mathrm{E}$. coli in the uterine fluids.

Urinary tract obstruction or rupture could lead to increased serum urea and creatinine concentrations that, when not excreted properly, increase in plasma, leading to azotemia (TYAGI; AEDDULA, 2021). The occurrence of proteinuria in dogs with pyometra is more frequent than azotemia, due to focal glomerulosclerosis, which leads to the passage of protein into the urine, and require monitoring after ovariohysterectomy (MADDENS et al., 2011).

Although increased, the values of the general average of creatinine in bitches with pyometra and in the different groups (types and age groups) were still within the reference values for the species, which may have occurred due to the search for veterinary care, leading to an early diagnosis, before serious kidney injury had occurred (BRAUN and LEFEBVRE, 2008).

ALT and ALP are the two hepatic enzymes used in clinical evaluation and when their activity is increased, it may be suggestive of liver damage, because they spill into the bloodstream during hepatopathy (MCGILL, 2016), even though ALP is not a specific marker for liver function, as its increase may also be of bone origin, induced by corticosteroids or different

\section{References}

BARSANTI, J.A. Genitourinary Infections. In: Greene, C.E. (Ed). Infectious Diseases of the Dog and Cat. 4. ed. Missouri: Saunders, p. 1013-1044, 2012.

COGGAN, J.A. Estudo microbiológico de conteúdo intrauterino e histopatológico de útero de cadelas com piometra e pesquisa de fatores de virulência em cepas de E. coli e o potencial risco à saúde humana. 2005. 156f. São Paulo, SP. Dissertação (Mestrado em Medicina Veterinária) -Universidade de São Paulo.

COGGAN, J.A.; MELVILLE, P.A.; DE OLIVEIRA, C.M.

Microbiological and histopathological aspects of canine pyometra. Brazilian Journal of Microbiology, v. 39, p. 477-483, 2008.

DE LOOR, J.; DAMINET, S.; SMETS, P.; MADDENS, B; MEYER, E. Urinary biomarkers for acute kidney injury in dogs. J. Vet. Intern. Med. v. 27, p. 998-1010, 2013.

DE SCHEPPER, J.; STOCK, V.; CAPIAU, E. The characteristic pattern of aspartate aminotransferase and alanine aminotransferase in the bitch with the cystic hyperplasia piometra complex: Effect of medical or surgical treatment. Veterinary research communications, v. 11, n. 1, p. 65-75, 1987.

EGENVALL, A.; HAGMAN, R.; BONNETT, B.N. Breed risk of pyometra in insured dogs in Sweden. Journal of Veterinary Internal Medicine, v. 15, n. 6, p. 530-538, 2001. classes of drugs (DE SCHEPPER et al., 1987; GWALTNEYBRANT, 2016).

In this study, ALP was above the reference values for the species in $52.2 \%$ of females studied, and ALT in only $3.3 \%$ of them. ALP can also be above the reference values due to elevation of intrahepatic cholestasis or stress and pain from the infectious condition (LASSEND, 2007). Therefore, ALP is less specific than ALT in detecting liver inflammation (GWALTNEY-BRANT, 2016). It is often used the ALP/ALT ratio to classify extrahepatic and hepatic damage, with an ALP/ALT proportion of 2:1 signifying hepatic injury (OZER et al., 2008).

Additionally, alkaline phosphatase is associated with the prognosis of the animal, being worse with higher blood levels of the enzyme (TRAUTWEIN et al., 2017). The average serum levels of ALT were within the reference values for the species in the different groups studied. This finding was also reported in other studies (DE SCHEPPER et al., 1987; KAYMAZ et al., 1999), indicating the reduced rate of severe liver damage in animals affected with pyometra.

As several authors have found, the bacteria most constantly isolated in bacterial cultures from the uterine contents of bitches with pyometra is Escherichia coli (HAGMAN and KUHN, 2002; COGGAN et al., 2008; KALENSKI et al., 2012; SHUKLA, 2012), which has also been confirmed in this study, and it could lead a transient glomerular and tubular dysfunction (MADDENS et al., 2010).

\section{Conclusion}

It was concluded that there was no effect of age and type of pyometra on the hematological and biochemical parameters studied, although bitches up to 8 years old were the most affected and open pyometra the most common, with Escherichia coli being the most frequent isolated microorganism from de uterus.

FELDMAN, E.C.; NELSON, R.W. Cystic endometrial hyperplasia/ piometra complex. In: Canine and Feline Endocrinology and Reproduction. 3 ed. St. Louis: Saunders, p. 852-866, 2004.

FIAMENGO, T.E.; RUNCAN, E.E.; PREMANANDAN, C.; BLAWUT, B.; SILVA, M.A.C. Evaluation of biofilm production by Escherichia coli isolated from clinical cases of canine piometra. Topics in Companion Animal Medicine, v. 39, 2020, Available at: https://www.sciencedirect.com/science/article/abs/pii/ S1938973620300271. Accessed: 04 may 2020.

FOSSUM, T.W. Surgery of the reproductive and genital systems. In: Small Animal Surgery. 4 ed. St. Louis: Mosby, p. 780-855, 2013.

GUPTA, A.K.; DHAMI, A.J.; PATEL, S.B. Evaluation of clinical biochemistry of blood in bitches affected with pyometra. Indian Journal of Animal Reproduction, v. 34, n. 1, p. 26-30,2013.

GWALTNEY-BRANT S. M. Veterinary forensic toxicology. Veterinary Pathology. v. 53, n. 5, p. 1067-1077, 2016.

HAGMAN, R. Clinical and Molecular Characteristics of pyometra in Female Dogs. Reproduction in Domestic Animals, v. 47, p. 6, p.323-325, 2012.

HAGMAN, R. Diagnostic and Prognostic Markers for Uterine Diseases in Dogs. Reproduction in Domestic Animals, v. 49, n. 2 , p. 16-20, 2014. 
HAGMAN, R.; KUHN, I. Escherichia coli strains isolated from the uterus and urinary bladder of bitches suffering from piometra: comparison by restriction enzyme digestion and pulsed-field gel electrophoresis. Veterinary Microbiology, v. 84, p. 143-153, 2002. J. De Loor, S. Daminet, P. Smets, B. Maddens, and E. Meyer JEAN-PIERRE BRAUN, J.-P.; LEFEBVRE, H.P. Kidney Function and Damage, In: KANEKO, J.; HARVEY, J.W.; BRUSS, M.L. Clinical Biochemistry of Domestic Animals. 6. ed. Academic Press, p. 485-528, 2008.

JIPTEAN, S.; AMBROSEN, A.; EMANUELSON, U. Closed cérvix is associated with more severe illness in dogs with pyometra. BMC Veterinary Research, v. 13, n. 1, p. 11, 2017.

KALENSKI, T.A.; REINOLDES, A.; KITSIS, M. Identificação das bactérias envolvidas na sepse grave de fêmeas caninas com piometra submetidas a ovariohisterectomia terapêutica. Brazilian Journal of Veterinary Research and Animal Science, v. 49, n. 2, p. 130-138, 2012.

KAYMAZ, M.; BASTAN, A.; ERUNAL, N. The use of laboratory findings in the diagnosis of $\mathrm{CEH}$-pyometra complex in the bitch. Turkish Journal of Veterinary Medicine and Animal Science, v. 23, p. 127-133, 1999

KUMAR, A.; SAXENA, A. Canine Pyometra: Current Perspectives on Causes and Management - A Review. The Indian Journal of Veterinary Sciences \& Biotechnology, v. 14, p. 52-56, 2018

LASSEND, E.D. Avaliação laboratorial do fígado. In: Thrall MA, editor. Hematologia e Bioquímica Clínica Veterinária.1 ed. São Paulo: Roca, 2007, 592p.

MADDENS, B.; DAMINET, S.; SMETS, P.; MEYER, E. Escherichia coli pyometra induces transient glomerular and tubular dysfunction in dogs. J. Vet. Intern. Med. v. 24, p. 12631270, 2010.

MADDENS, B.; HEIENE, R.; SMETS, P.; SVENSSON, M.; ARESU, L.; LUGT, J.; DAMINET, S.; MEYER, E. Evaluation of kidney injury in dogs with pyometra based on proteinuria, renal histomorphology, and urinary biomarkers. J. Vet. Intern. Med. v. 25, p. 1075-1083, 2011.

MAKRIS, K.; SPANOU, L. Acute kidney injury: definition, pathophysiology and clinical phenotypes. Clin Biochem Rev. v. 37 , n. 2, p. 85-98, 2016.

MARTINS, D.G.; APPARÍCIO, M.; VICENTE W.R.R.A survey of three years consultation: 119 cases of pyometra, prognosis and outcome. Journal of Animal Science Advances, v. 5, n. 2, p. 12021207, 2015.

MCGILL, M. R. The past and present of serum aminotransferases and the future of liver injury biomarkers. EXCLI Journal. v. 15, p. 817-828, 2016.

NGUYEN, H.B., RIVERS E.P., ABRAHAMIAN, F.M. Severe sepsis and septic shock: Review of literature and emergency department management guidelines. Annals of Emergency Medicine, v. 48, p. 28-54, 2006
OZER J., RATNER M., SHAW M., BAILEY W., SCHOMAKER $\mathrm{S}$. The current state of serum biomarkers of hepatotoxicity. Toxicology. v. 245, n. 3, p. 194-205, 2008.

PRAPAIWANA, N.; MANEE-INB, S.; OLANRATMANEEC, E.; SRISUWATANASAGULA, S. Expression of oxytocin, progesterone, and estrogen receptors in the reproductive tract of bitches with pyometra. Theriogenology, v. 89, p. 131-139, 2017.

SANT'ANNA, M.C.; GIORDANO, L.G.P.; FLAIBAN, K.K.M.C. Prognostic markers of canine piometra. Arquivo Brasileiro de Medicina Veterinária e Zootecnia, v. 66, p. 1711-1717, 2014.

SHAH, S.A.; SOOD, N.K.; WANI, B.M.; RATHER, M. A; BEIGH, A. B.; AMIN, U. Haemato-biochemical studies in canine pyometra. Journal of Pharmacognosy and Phytochemistry, v. 6, n. 4, p. 1417, 2017.

SHUKLA, S.P. Recent advances in canine pyometra. Indian Journal of Canine Practice, v. 4, p. 25-29, 2012.

SMITH, F.O. Canine Pyometra. Theriogenology, v.66, p.610-612, 2006.

SRINIVAS, M.; ANUSHA, K.; CHANDRA PRASAD, B.;

THANGAMANI, A. Clinico-pathological alterations in canine pyometra, Intas Polivet. v. 19, n. 2, p. 192-195, 2018.

STERMAN, A.A.; MANKIN, K.T.; BARTON, C.L. Stump pyometra secondary to human topical estrogen hormone exposure in a spayed female chihuahua. J. Am. Anim. Hosp. Assoc. v. 55, n. 6, p. 55604, 2019.

SUGIURA, K.; NISHIKAWA, M.; ISHIGURO, K.; TAJIMA, T., INABA, M.; TORII R. Effect of ovarian hormones on periodical changes in immune resistance associated with estrous cycle in the beagle bitch. Immunobiology, v. 209, p. 619-627, 2004.

TRAUTWEIN, L. G. C.; SANT'ANNA, M. C.; JUSTINO, R. C.; PRETTO GIORDANO, L.G.; FLAIBAN, K.K.M.C.; MARTINS, M.I.M. Piometra em cadelas: Relações entre o prognóstico clínico e o diagnóstico laboratorial. Ciência Animal Brasileira, v. 18, p. 1-10, 2017.

TYAGI, A.; AEDDULA, N.R. Azotemia. Treasure Island: StatPearls Publishing; Available from: https://www.ncbi.nlm.nih.gov/books/ NBK538145/. Accessed: 04 jul 2021.

Urinary Biomarkers for Acute Kidney Injury in Dogs

VOLPATO, R. Análise clínica e imunohistoquímica do útero e cérvix de cadelas com o diagnóstico de piometra. 2011. $134 \mathrm{f}$. Botucatu, SP. Dissertação (Mestrado em Reprodução Animal) - Faculdade de Medicina Veterinária e Zootecnia, Universidade Estadual Paulista Júlio de Mesquita Filho.

WEISS, R.R.; CALOMENO, M.A.; SOUSA, R.S.; BRIERSDORF, S.M.; CALOMENO, R.A.; MURADÁS, P. Avaliação histopatológica, hormonal e bacteriológica da piometra na cadela. Archives of Veterinary Science, v. 9, n. 2, p. 81-87, 2004. 